\title{
Beta diversity, community composition and structure of high altitude grasslands along an altitudinal gradient in southeastern Brazil
}

\author{
Prímula Viana Campos ${ }^{1}$, Pedro Manuel Villa ${ }^{1,2}$, Carlos Ernesto Gonçalves Reynaud Schaefer ${ }^{3}$,
} Jaquelina Alves Nunes ${ }^{4}$, Stefan Porembski ${ }^{5}$ \& Andreza Viana Neri ${ }^{1 *}$

1. Department of Plant Biology, Laboratory of Ecology and Evolution of Plants, Campus Universitário, Universidade Federal de Viçosa, 36570-900, Viçosa-MG, Brazil; primula.vc@gmail.com, andreza.neri@ufv.br

2. Departament of Forestry Engineering, Campus Universitário, Universidade Federal de Viçosa, 36570-900, ViçosaMG, Brazil; pedro.villa@ufv.br

3. Departament of Soil, Campus Universitário, Universidade Federal de Viçosa, 36570-900, Viçosa-MG, Brazil; carlos.schaefer@ufv.br

4. Universidade do Estado de Minas Gerais. Rua dos estudantes, 43, Santa Emília, 3680-000, Carangola-MG, Brazil; jaquelinabot@hotmail.com

5. Institut für Biowissenschaften, Allgemeine und Spezielle Botanik, Universität Rostock, Wismarsche Str. 44/45, D-18057 Rostock, Germany; stefan.porembski@uni-rostock.de

* Correspondence

$$
\text { Received 18-VI-2019. Corrected 21-IV-2020. Accepted 03-VII-2020. }
$$

\begin{abstract}
Introduction: Studies on how the altitudinal gradient determines community composition and structure in tropical high altitude grasslands are limited. Objective: To evaluate the plant community composition and structure and their relationship with altitude and soil properties along an altitudinal gradient of three granitic rocky outcrops at the Serra do Brigadeiro State Park, Minas Gerais, in southeastern Brazil. Methods: In each selected site, 100 plots of $1 \times 1 \mathrm{~m}$ were established, totalizing 300 plots in the study area. We compared floristic composition, relative coverage and abundance among sites. We performed beta diversity analysis. We also performed an indicator species analysis and a canonical correlation analysis to investigate possible relations between abiotic (soil and altitude) and biotic (indicator species abundances) variables. Results: We sampled a total of 9276 individuals belonging to 39 families and 102 species. Significant differences were observed among sites regarding composition, abundance and coverage. The indicator species analysis revealed that 57 species $(55.88 \%)$ were indicators. The distribution of indicator species abundances was correlated with environmental variables. Conclusions: It was observed that altitude and soil play an important role in controlling community composition and structure, beta diversity and species distribution in the highland grasslands studied.
\end{abstract}

Key words: indicator species; mountain vegetation; rocky outcrops; plant coverage; soil-vegetation relationship.

Campos, P.V., Villa, P.M., Schaefer, C.E.G.R., Nunes, J.A., Porembski, S., \& Neri, A.V. (2020). Beta diversity, community composition and structure of high altitude grasslands along an altitudinal gradient in southeastern Brazil. Revista de Biologia Tropical, 68(3), 977-986.

Mountain ecosystems are home to a significant portion of global biodiversity, being characterized by a high number of endemic species due to a large variability in abiotic conditions (Körner, 2007). Thus, plant communities can be influenced by local soil conditions along altitudinal gradients (Neri et al., 2016). Altitude is an important driver that promotes environmental heterogeneity at a small geographical scale (Körner, 2007), affecting the physico-chemical properties of soils, plant community composition, beta diversity, 
community structure and spatial distribution of species (Körner, 2007). The simplest meaning of taxonomic beta diversity and one of the most used is the percentage of dissimilarity in species composition between two communities (Koleff, Gaston, \& Lennon, 2003). Thus, most studies on altitudinal gradients in tropical mountains mainly focused on species diversity, but not on community composition and dissimilarities in species composition (taxonomic beta diversity), which remains poorly understood along elevation gradient in mountain system. Plant communities associated with granitic/ gneiss outcrops are commonly known as high altitude grasslands (HAG) (Safford, 1999b), which occur on the highest mountain ranges in Eastern South America (i.e. Serra do Mar, Mantiqueira and Caparaó), generally above 1 $500 \mathrm{~m}$ (Safford \& Martinelli, 2000). Likewise, rocky outcrops in HAG are harsh environments for plant communities (Jacobi \& Carmo, 2011), mainly because the soil nutrient resources are severely limited (Schaefer et al., 2016).

Several studies point to the soil as a localscale driver of vegetation structure, representing the main physical component influencing the species composition in HAG (Messias, Leite, Meira-Neto, Kozovits, \& Tavares, 2013; Le Stradic, Buisson, \& Fernandes, 2015) and together with altitude, determine the spatial distribution of plants (Neri et al., 2016). Studies focused on nutrient availability and soil texture suggest that vegetation parameters are mainly influenced by the cation exchange capacity, $\mathrm{pH}$, aluminium concentration and the amount of sand, all simultaneously acting as filters in the selection of species (Schaefer et al., 2016). In addition, in HAG small altimetric differences show to be a very important driver in the community assembly, influencing structural patterns (Campos et al., 2018). However, few studies have been conducted on the relationships between environmental conditions (e.g. altitude and soil properties) and plant communities and taxonomic beta diversity in HAG on granitic rocks.

In this context, we aimed to evaluate the plant community composition and structure and their relationship with altitude and soil properties along the altitudinal gradient in the Atlantic Rain Forest of Southeastern Brazil. We selected three granitic rock outcrops within the Serra do Brigadeiro State Park to answer the following questions: (i) how do floristic composition, abundance and plant coverage change along the altitudinal gradient?, (ii) how are indicator species distributed between specific sites along the altitudinal gradient? and (iii) how does the altitudinal gradient determine changes in the partitioning of beta diversity in granitic highlands? We assume that total beta diversity and turnover beta diversity should increase with decreasing altitude.

\section{MATERIALS AND METHODS}

Study site: The study was conducted on three peaks at the "Serra das Cabeças" (Three Head Range): Pico do Mamute (MP, 1857 m), Pico do Elefante (EP, $1790 \mathrm{~m}$ ) and Pico do Totem (TDP, $1725 \mathrm{~m}$ ). This range is located in Serra do Brigadeiro State Park, state of Minas Gerais, Southeastern Brazil and surrounded by Atlantic Rain Forest $\left(42^{\circ} 20^{\prime}-42^{\circ} 40^{\prime} \mathrm{S}\right.$ \& $\left.20^{\circ} 20^{\prime}-21^{\circ} 00^{\prime} \mathrm{W}\right)$. The region has a subtropical mesothermal climate $\left(\mathrm{C}_{\mathrm{Wb}}\right)$, with a mean annual temperature of $18{ }^{\circ} \mathrm{C}$. The mean annual precipitation of $1500 \mathrm{~mm}$, with a dry period from June through August (Benites et al., 2003).

The park has a rugged topography, alternating high escarpments and massifs with extensive areas of rocky outcrops, modeled by plutonic rocks (granite) and high-grade metamorphic (migmatites, gneiss) (Benites, Schaefer, Simas, \& Santos, 2007). Low forests and scrubs are found on deeper soil.

Data collection: Vascular plant species were sampled on rocky outcrops, systemically selected from all three sampled peaks. In these rocky outcrops, as dominant habitat type, we randomly distributed 100 plots $(1 \times 1 \mathrm{~m})$ in each of the three sites, thus totalizing 300 plots. The sampling was performed at MP in plots ranging from 1813 to 1857 m.a.s.l. altitude; 
at EP, from 1732 to 1790 m.a.s.l.; and at TDP, from 1665 to 1725 m.a.s.l. The structure of plant communities was evaluated by BraunBlanquet coverage-abundance scale (1979). In addition, the number of individuals from each species was counted in each plot. For matforming species, each clump was considered a single individual. The fertile botanical samples were stored in the herbarium VIC at Universidade Federal de Viçosa (Minas Gerais, Brazil).

In each plot the altitude and soil were sampled. The composite sample of surface soil (0-10 cm depth) was collected. The samples were air-dried and sifted through a $2 \mathrm{~mm}$ mesh. Physical and chemical analyses were conducted at the Universidade Federal de Viçosa. The analyses included granulometry (clay, silt and coarse and fine sand content); active acidity $(\mathrm{pH})$ in water; exchangeable potassium $\left(\mathrm{K}^{+}\right)$, sodium $\left(\mathrm{Na}^{+}\right)$, calcium $\left(\mathrm{Ca}^{2+}\right)$, magnesium $\left(\mathrm{Mg}^{2+}\right)$, aluminum $\left(\mathrm{Al}^{3+}\right)$; potential acidity $(\mathrm{H}$ $+\mathrm{Al}$ ); available $\mathrm{P}$; remaining $\mathrm{P}$ (P-rem); sum of bases (BS); base saturation (V); aluminium saturation $(\mathrm{m})$; total cation exchange capacity (CEC) including micronutrients ( $\mathrm{Zn}, \mathrm{Fe}, \mathrm{Mn}$ and $\mathrm{Cu})$; and organic matter content $(\mathrm{OM})$.

Data analysis: We estimated species richness using individual-based rarefaction and extrapolation curves (Chao et al., 2014) and there are no differences between sites. Thus, follow our research questions the floristic similarity between sites was calculated through the Jaccard index (e.g. Campos et al., 2018). The importance value (IV) of each species was calculated by the sum of its relative density, relative frequency and relative coverage (Braun-Blanquet, 1979).

We evaluated the differences of taxonomic compositions among plant communities and sites using three pairwise beta-diversity components: i) Bsor, accounts for the total compositional variation between assemblages (including both turnover and nestedness patterns); ii) $\beta$ sim, captures only compositional changes due to species turnover; iii) $\beta$ sne, represents the losses from site to site (Baselga, 2017). $\beta$ sne is a resultant dissimilarity and is calculated as the difference between $\beta$ sor and $\beta$ sim (Baselga, 2017).

In order to assess the strength of association between species abundance and the three sites, we performed an indicator value analysis (IndVal) approach. (Dufrêne \& Legendre, 1997; De Cáceres, Legendre, \& Moretti, 2010), yielding a percentage indicator value (IndVal) for each species. The analysis was performed with software R 3.4.3 (R Core Team, 2018), using the 'multipatt' function in the 'indicspecies' package (De Cáceres \& Jansen, 2016). The Monte Carlo permutation tests (999) were performed to assess the statistical significance of the association between species and site groups (Legendre \& Legendre, 2012).

Data normality and distribution were verified by Shapiro-Wilk test. Variation in the main community structure parameters (coverage and abundance) was compared among sampled sites by multivariate analysis of variance with 1000 permutations (PERMANOVA) based on Bray-Curtis distances and a post hoc test at 5 $\%$ significance level. We then compared the variation in beta diversity components ( $\beta$ sor, $\beta$ sim, $\beta$ sne) among sampled sites with a oneway ANOVA followed by a post hoc Tukey's test $(\mathrm{HSD}=0.05)$ for normally distributed data (Crawley, 2013).

Soil variables were summarized by using the principal component analysis (PCA). To investigate possible relations between abiotic (soil and altitude) and biotic (indicator species abundances) variables we used the Canonical Correspondence Analysis (CCA). The main matrix consisted of species selected by the indicator value analysis (IndVal). The ordination analyses were performed using PC-ORD version 6.0 (McCune \& Mefford, 2011).

\section{RESULTS}

Species richness and community composition: Overall, we sampled a total of 9276 individuals belonging to 39 families and 102 species. The TDP and EP showed the same number of species (66), followed by MP with 48 species (Fig. 1). 


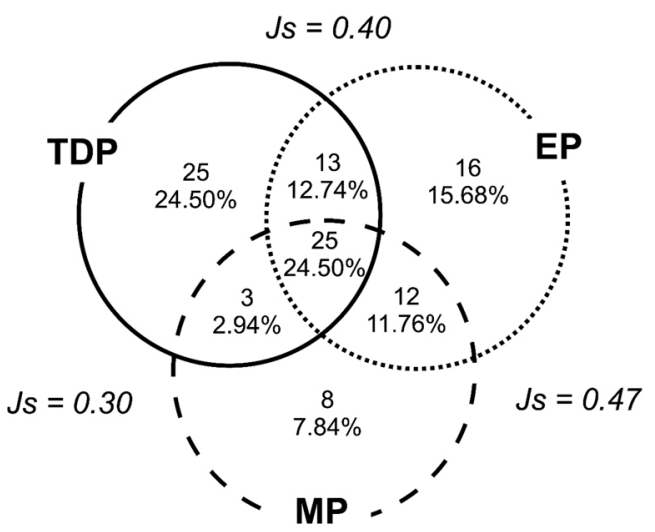

Fig. 1. Species richness of plant communities in three sites of the Serra do Brigadeiro State Park, Minas Gerais, Brazil. Pico do Totem (TDP, 66 spp.), Pico do Elefante (EP, 66 spp.), Pico do Mamute (MP, 48 spp.).

The dominant families on all peaks were Asteraceae and Orchidaceae (11 species), followed by Melastomataceae (7) and Bromeliaceae (6), with 40.39, 43.93 and $42 \%$ of total richness for TDP, EP and MP, respectively. Most families at each site occurred with just one or two species. Of the total number of identified species, 49 (48.03\%) occurred exclusively on one of the peaks, $28(27.45 \%)$ were common to two sites and $25(24.50 \%)$ occurred in all three sites. Floristic similarities between sites according to Jaccard index were: EP and MP (47\%) > TDP and EP (40\%) > TDP and MP (30\%).
We observed differences in total $\beta$-diversity and replacement $\beta$-diversity components among sites, but not in nestedness (Fig. 2). Among-sites $\beta$-diversity was higher in observed than in expected values with significant differences. Finally, the $\beta$-diversity showed a clear pattern that tends to decrease with elevation. The taxonomic and functional turnover and $\beta$-diversity were higher than nestedness-resultant component.

Community structure: The sampled sites differed in relative values of abundance (PERMANOVA, $\mathrm{df}=298, \mathrm{~F}=14.56, \mathrm{P}<0.001)$ and coverage (PERMANOVA, $\mathrm{df}=298, \mathrm{~F}=24.23$, $\mathrm{P}<0.001)$ of their main species.

The 10 most abundant species, with highest importance values (IV), that is, less than 20 $\%$ of total richness, concentrate approximately $61.80,58.63$ and $69.66 \%$ of the total IV for TDP, EP and MP, respectively. In addition, among the 10 species with highest importance values, EP and MP shared the highest number of species: Anemia villosa, Pitcairnia carinata, Vernonia decumbens and Eupatorium intermedium, which are characterized by higher relative values of density and coverage.

The sites on TDP showed the highest number of exclusive species among the 10 most dominants species (highest IV): Vellozia variegata, Trilepis lhotzkiana, Tibouchina manicata, Anemia sp., Pitcairnia decidua and Polygala
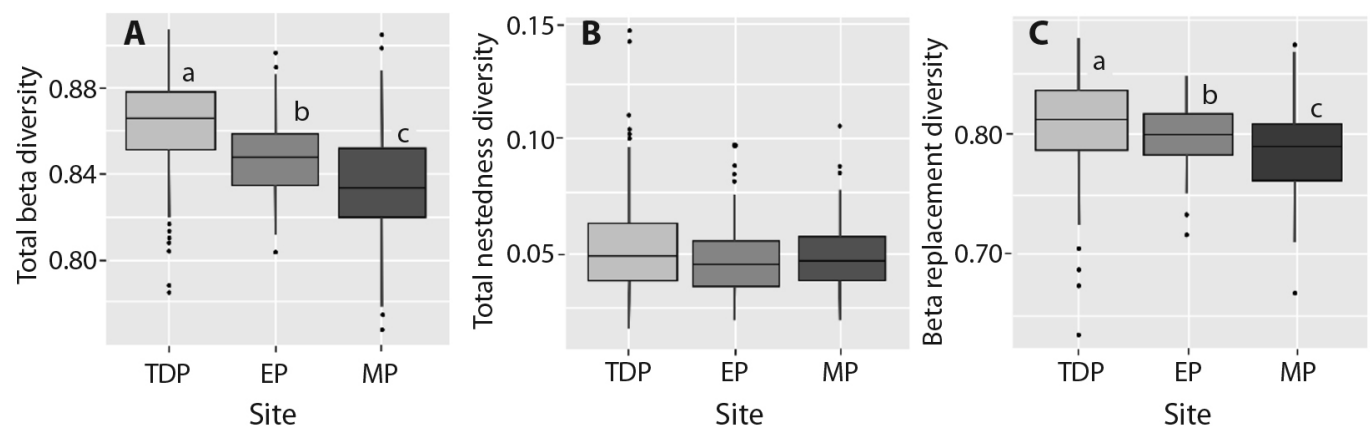

Fig. 2. Differences in the taxonomic components of beta diversity at the Serra do Brigadeiro State Park, Minas Gerais, Brazil. The A. taxonomic $\beta$-diversity ( $\beta$ sor), B. nestedness-resultant $(\beta$ sne) and $\mathbf{C}$. turnover $(\beta$ sim) components are indicated. Pico do Totem (TDP), Pico do Elefante (EP), Pico do Mamute (MP). Different letters indicate significant differences (P< $0.05)$ among sites. 
TABLE 1

Indicator species analysis (IndVal) of study sites and site group combinations at the Serra do Brigadeiro State Park, Minas Gerais, Brazil

\begin{tabular}{|c|c|c|c|c|c|}
\hline Site & Species & $\mathrm{S}$ & $\mathrm{F}$ & IndVal & P-value \\
\hline \multirow[t]{15}{*}{ TDP } & Vellozia variegata Goethart \& Henrard & 0.82 & 0.39 & 0.56 & $0.001 * * *$ \\
\hline & Anemia sp. 1 & 1 & 0.26 & 0.51 & $0.001 * * *$ \\
\hline & Pitcairnia decidua L.B. Sm. & 0.99 & 0.17 & 0.41 & $0.001 * * *$ \\
\hline & Polygala sp. & 1 & 0.12 & 0.34 & $0.001 * * *$ \\
\hline & Trimezia sp. & 1 & 0.12 & 0.34 & $0.001 * * *$ \\
\hline & Unidentified 2 & 1 & 0.11 & 0.33 & $0.001 * * *$ \\
\hline & Huperzia pungentifolia (Silveira) B. Øllg. & 0.87 & 0.09 & 0.28 & $0.005 * *$ \\
\hline & Zygopetalum mackaii Hook. & 1 & 0.07 & 0.26 & $0.001 * * *$ \\
\hline & Bromelia sp. 1 & 0.78 & 0.08 & 0.25 & $0.033^{*}$ \\
\hline & Fuchsia regia (Vell.) Munz & 1 & 0.06 & 0.24 & $0.010^{* *}$ \\
\hline & Unidentified 3 & 1 & 0.06 & 0.24 & $0.003 * *$ \\
\hline & Vernonia geminata Kunth & 1 & 0.06 & 0.24 & $0.004 * *$ \\
\hline & Doryopteris collina (Raddi) J. Sm. & 1 & 0.05 & 0.22 & $0.012 *$ \\
\hline & Dioidea $\mathrm{sp}$. & 0.93 & 0.05 & 0.21 & $0.018 *$ \\
\hline & Behuria comosa R. Tavares, Baumgratz \& R. Goldenb. & 1 & 0.04 & 0.2 & $0.036^{*}$ \\
\hline \multirow[t]{17}{*}{ EP } & Poaceae sp. 5 & 0.84 & 0.48 & 0.64 & $0.001 * * *$ \\
\hline & Croton migrans Casar. & 0.82 & 0.36 & 0.54 & $0.001 * * *$ \\
\hline & Pitcairnia carinata $\mathrm{Mez}$ & 0.82 & 0.32 & 0.52 & $0.001 * * *$ \\
\hline & Peperomia galioides Kunth & 0.75 & 0.27 & 0.46 & $0.001 * * *$ \\
\hline & Tibouchina sp.1 & 0.9 & 0.21 & 0.44 & $0.001 * * *$ \\
\hline & Dyckia bracteata (Wittm.) Mez & 1 & 0.15 & 0.39 & $0.001 * * *$ \\
\hline & Lippia triplinervis Gardner & 0.81 & 0.15 & 0.35 & $0.001 * * *$ \\
\hline & Lycopodium clavatum $\mathrm{L}$. & 0.74 & 0.14 & 0.32 & $0.002 * *$ \\
\hline & Pleurothallis prolifera Herb. exLindl & 0.91 & 0.09 & 0.29 & $0.002 * *$ \\
\hline & Esterhazya splendida J.C. Mikan & 1 & 0.08 & 0.28 & $0.001 * * *$ \\
\hline & Cuphea racemosa (L. f.) Spreng. & 0.87 & 0.09 & 0.28 & $0.002 * *$ \\
\hline & Pteridium arachnoideum (Kaulf.) Maxon & 0.88 & 0.05 & 0.21 & $0.016^{*}$ \\
\hline & Prescottia montana Barb. Rodr. & 0.83 & 0.04 & 0.18 & $0.038^{*}$ \\
\hline & Vernonia discolor (Spreng.) Less. & 0.83 & 0.04 & 0.18 & $0.040^{*}$ \\
\hline & Pleurothallis teres Lindl. & 1 & 0.03 & 0.17 & $0.041^{*}$ \\
\hline & Serjania sp. & 1 & 0.03 & 0.17 & $0.028^{*}$ \\
\hline & Unidentified 5 & 1 & 0.03 & 0.17 & $0.037^{*}$ \\
\hline \multirow[t]{9}{*}{ MP } & Rhynchospora emaciata (Nees) Boeckeler & 0.66 & 0.67 & 0.66 & $0.001 * * *$ \\
\hline & Lantana sp. & 0.98 & 0.32 & 0.56 & $0.001 * * *$ \\
\hline & Axonopus pressus (NeesexSteud.) Parodi & 1 & 0.25 & 0.5 & $0.001 * * *$ \\
\hline & Poaceaesp. 7 & 1 & 0.16 & 0.4 & $0.001 * * *$ \\
\hline & Poaceaesp. 6 & 1 & 0.12 & 0.34 & $0.001 * * *$ \\
\hline & Abatia americana (Gardner) Eichler & 0.85 & 0.09 & 0.27 & $0.006 * *$ \\
\hline & Poaceaesp. 4 & 1 & 0.06 & 0.24 & $0.004 * *$ \\
\hline & Lobelia sp. & 1 & 0.04 & 0.2 & $0.042 *$ \\
\hline & Unidentified 7 & 1 & 0.04 & 0.2 & $0.039^{*}$ \\
\hline \multirow[t]{4}{*}{$\mathbf{E P}+\mathbf{M P}$} & Anemia villosa Humb. \&Bonpl. exWilld. & 1 & 0.58 & 0.7 & $0.001 * * *$ \\
\hline & Baccharis platypoda DC. & 0.86 & 0.49 & 0.65 & $0.001 * * *$ \\
\hline & Vernonia decumbens Gardner & 0.96 & 0.43 & 0.64 & $0.001 * * *$ \\
\hline & Cleistes gracilis(Barb. Rodr.) Schltr. & 1 & 0.17 & 0.42 & $0.001 * * *$ \\
\hline
\end{tabular}


TABLE 1 (Continued)

\begin{tabular}{clcccc}
\multicolumn{1}{c}{ Site } & \multicolumn{1}{c}{ Species } & S & F & IndVal & P-value \\
& Eupatorium intermedium DC. & 0.95 & 0.15 & 0.38 & $0.001^{* * *}$ \\
& Oncidium barbaceniae Lindl. & 0.93 & 0.15 & 0.37 & $0.004^{* *}$ \\
& Agarista niederleinii (Sleumer) Judd & 1 & 0.13 & 0.36 & $0.001^{* * *}$ \\
EP+TDP & Achyrocline satureioides (Lam.) DC. & 0.96 & 0.08 & 0.28 & $0.026^{*}$ \\
& Bulbostylis scabra (J. Presl \& C. Presl) C.B. Clarke & 0.86 & 0.37 & 0.56 & $0.001^{* * *}$ \\
& Doryopteris crenulans (Fée) Christ & 1 & 0.29 & 0.54 & $0.001^{* * *}$ \\
& Trilepis lhotzkiana Neesex Arn. & 0.93 & 0.3 & 0.53 & $0.001^{* * *}$ \\
& Marcetia taxifolia (A. St.-Hil.) DC. & 0.86 & 0.15 & 0.36 & $0.009^{* *}$ \\
& Spermacoce poaya A. St.-Hil. & 1 & 0.09 & 0.31 & $0.003^{* *}$ \\
& Rhynchospora splendens Lindm. & 1 & 0.05 & 0.23 & $0.042^{*}$ \\
MP+TDP & Tibouchinamanicata Cogn. & 0.84 & 0.41 & 0.58 & $0.001^{* * *}$ \\
& Unidentified 8 & 1 & 0.11 & 0.33 & $0.002^{* *}$ \\
\hline
\end{tabular}

$\mathrm{TDP}=$ Pico do Totem, $\mathrm{EP}=$ Pico do Elefante, $\mathrm{MP}=$ Pico do Mamute.

$*=\mathrm{P} \leq 0.05, * *=\mathrm{P} \leq 0.01, * * *=\mathrm{P} \leq 0.001$.

sp. At this site, Bulbostylis scabra occurred with a high cover percentage (21.82\%).

Indicator species analysis: This analysis revealed that $57(55.88 \%)$ were indicators of all three site group categories (TDP, EP, MP) as well as of all three categories of site group combinations (TDP and EP; TDP and MP; and EP and MP) (Table 1). Of these indicator species, $49.12 \%$ had maximum specificity, meaning that they occurred only at one site. No species showed maximum fidelity, indicating low proportion of sample units in a particular site containing the analyzed species.

Soil-altitude-vegetation relationship: The CCA ordination diagram clearly separated groups according to their soil and altitudinal variations (Fig. 3A). The first axis of the CCA biplot explained $50.98 \%$ of the species composition with differences in soil properties, while the second axis explained $18.20 \%$. The first group, formed by TDP plots correlated with fine sand, while the second, formed by MP plots, correlated with altitude, OM, CEC, $\mathrm{pH}$ and silt. For indicator species abundance, the first axis was negatively correlated with $\mathrm{pH}$, OM, CEC, silt and altitude and positively with fine sand. Among the variables, those with high correlations with the structural parameters of vegetation $(R>0.5)$ were altitude $(R=-0.979$, $\mathrm{P}<0.05)$ and CEC $(\mathrm{R}=-0.720, \mathrm{P}<0.05)$. The distribution of indicator species abundances in relation to environmental variables followed a similar pattern (Fig. 3B).

\section{DISCUSSION}

We described relevant community composition and structural differences linked to variation in soil and altitude on HAG. We were also able to show that there is a high proportion of indicator species, which are restricted to each peak that are related to these environmental variables, considering the short geographical distance among the peaks. In general, soil conditions between the three adjacent outcrop communities showed a marked environmental heterogeneity at the landscape level, where physical and chemical properties of soil, as well as altitude, can drive differences in community composition and structure of vegetation, but not species richness. Furthermore, the result demonstrates our prediction that turnover beta diversity increases with decreasing altitude, probably due to the influence of altitude as an important environmental filter previously studied (e.g. Körner, 2007).

With regard to the most species rich families our data are consistent with results of other 
A

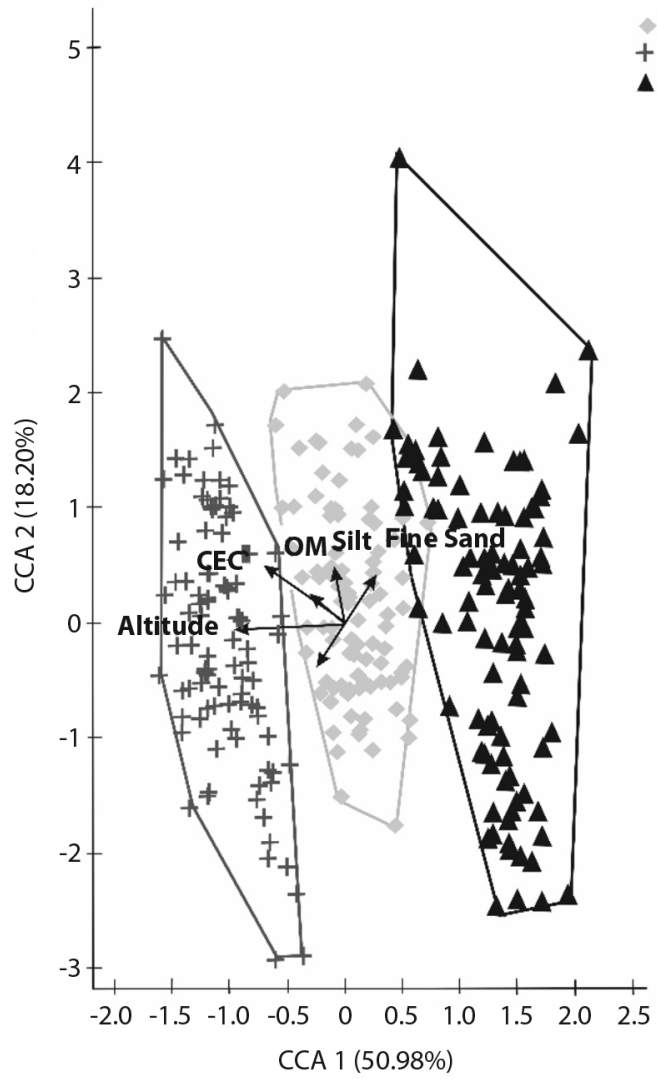

B

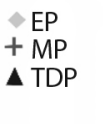

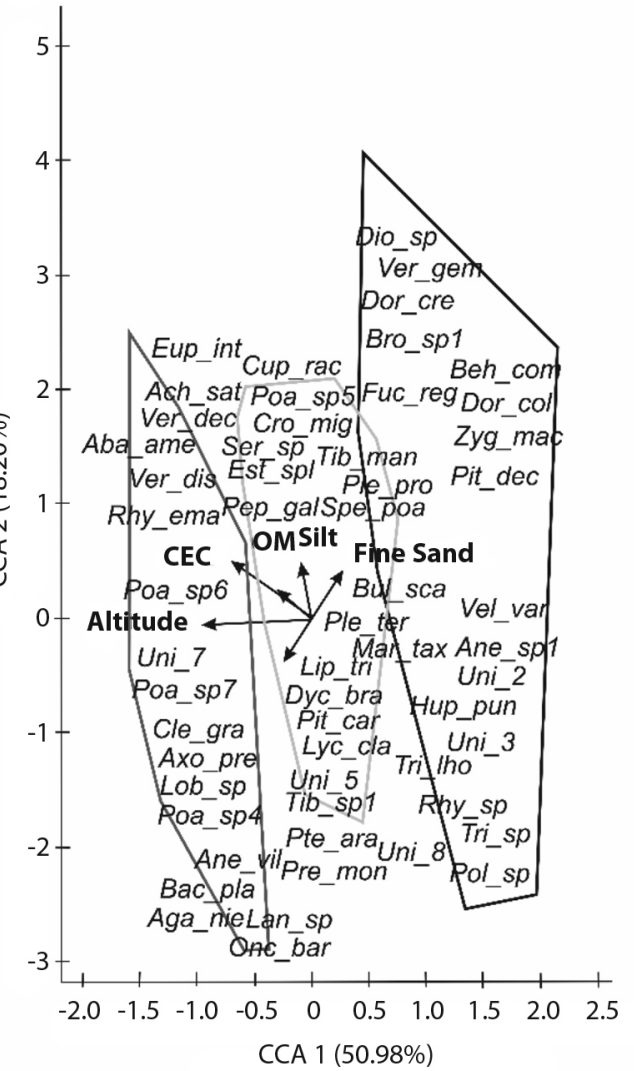

Fig. 3. Canonical correspondence analysis (CCA) ordination of environmental variables and species abundance: A. sampling sites $\times$ environmental variables and $\mathbf{B}$. distribution of indicator species abundance in the three study sites at the Serra do Brigadeiro State Park, Minas Gerais, Brazil. Pico do Totem (TDP), Pico do Elefante (EP), Pico do Mamute (MP). Species codes: Abatia americana (Aba_ame); Achyrocline satureioides (Ach_sat); Agarista niederleinii (Aga_nie); Anemia sp. (Ane_sp.), A.villosa (Ane_vil); Axonopus pressus (Axo_pre); Baccharis platypoda (Bac_pla); Behuria comosa (Beh_com); Bromelia sp. (Bro_sp.); Bulbostylis scabra (Bul_sca); Cleistes gracilis (Cle_gra); Croton migrans (Cro_mig); Cuphea racemosa (Cup rac); Dioidea sp. (Dio_sp.); Doryopteris collina (Dor_col), D. crenulans (Dor cre); Dyckia bracteata (Dyc_bra); Esterhazya splendida (Est_spl); Eupatorium intermedium (Eup_int); Fuchsia regia (Fuc_reg); Huperzia pungentifolia (Hup_pun); Lantana sp. (Lan_sp.); Lippia triplinervis (Lip_tri); Lobelia sp. (Lob_sp.); Lycopodium clavatum (Lyc_cla); Marcetia taxifolia (Mar_tax); Oncidium barbaceniae (Onc_bar); Peperomia galioides (Pep_gal); Pitcairnia decidua (Pit_dec), P. carinata (Pit_car); Pleurothallis prolifera (Ple_pro), P. teres (Ple_ter); Poaceae sp. 4-7 (Poa_sp.4), (Poa_sp5), (Poa_sp6), (Poa_sp.7); Polygala sp. (Pol_sp.); Prescottia montana (Pre_mon); Pteridium arachnoideum (Pte_ ara); Rhynchospora emaciata (Rhy_ema), R. splendens (Rhy_spl); Serjania sp. (Ser_sp.); Spermacoce poaya (Spe_poa); Tibouchina sp. (Tib_sp.), T. manicata (Tib_man), Trilepsis Thotzkiana (Tri_lho); Trimezia sp. (Tri_sp.); Unidentified 2 (Uni_2), 3 (Uni_3), 5 (Uni_5), 7 (Uni_7), 8 (Uni_8); Vellozia variegata (Vel_var); Vernonia decumbens (Ver_dec), V. discolor (Ver_dis); Vernonia geminata (Ver_gem); Zygopetalum brachypetalum (Zyg_bra).

surveys on HAG (Safford, 1999a; Tinti et al., 2015; Campos et al., 2018) as well as other rupestrian vegetation types in Southeastern Brazil (Conceição \& Pirani, 2007; Porembski, 2007). We can highlight Asteraceae that generally is the richest family in floristic inventories in all neotropical mountain ecosystems in South and Central America (Safford, 2007). The richness of Asteraceae is assigned to their ability to colonize harsh environments under severe stress conditions, with a broad array of adaptations to nutrient deficiency, fire, acidity, 
Al toxicity, cold and lack of water amongst others. We presume that all these characteristics of the family, allows for a relatively high contribution in the species community turnover and lower nestedness along the altitudinal gradient. This result is confirmed by the separation of the groups according to environmental variables, which may be related to the distribution of the abundance of indicator species at the three sites studied.

At a continental scale, Safford (2007) pointed out that there is a remarkable floristic conformity at the genus and species level between Andean paramos and Brazilian high altitude outcrops (e.g. Baccharis sp., Eryngium sp., Lycopodium clavatum, Achyrocline satureioides, mainly due to climatic similarities resulting from the altitudinal gradient. In addition to the pronounced floristic divergence between mountain ecosystems, Tinti et al. (2015) attribute the high number of in situ species to the environmental heterogeneity of rock outcrops, offering a myriad of microhabitats.

A higher number of indicator species with maximum specificity $(\mathrm{S}=1.00)$ and the absence of indicator species with maximum fidelity $(F=1.00)$ indicate the presence of a significant number of species with distribution restricted to a given site. At EP and MP indicator species encompassed c. $74 \%$ of the total species number and c. $86 \%$ of the indicator species with maximum specificity.MP, the site with the highest altitude, had the highest number of species with maximum specificity $(50 \%)$. This could be a consequence of specific environmental conditions. All indicator species were correlated with altitude and soil properties according to the site in which they occurred. Differences in indicator species distribution may be associated with sites having high and low altitude values (Campos et al., 2018), as well as physicochemical properties of the soil (Dludlu, Chimphango, Stirton, \& Muasya, 2017). Such environmental characteristics could select for species which are better adapted to the environmental conditions on HAG.

Thus, with respect to structural parameters, indicator species mostly correlated with fine sand and have been those with the highest IV for TDP: Bulbostylis scabra, Vellozia variegata, Doryopteris crenulans, Trilepis lhotzkiana, Tibouchina manicata and Anemia sp. Indicator species that correlated with higher altitude, $\mathrm{CEC}, \mathrm{pH}$, silt and OM were those with the highest IV for EP and MP: Rhynchospora emaciata, Anemia villosa, Baccharis platypoda, Vernonia decumbens, Lantana sp. and Axonopus compressus. The first is formed by species correlated with sandy soils, dominant at TDP, such as Vellozia variegata, Trilepis lhotzkiana and Bulbostylis scabra. Velloziaceae and Cyperaceae often occur in rupestrian vegetation (Conceição \& Pirani, 2007). Some of them are characterized by having specific adaptation strategies such as desiccation tolerance, since sandy soils have lower water retention (Porembski, 2007). The second group is formed by species correlated with organic matter, silt, $\mathrm{CEC}, \mathrm{pH}$ and altitude, dominant at MP and EP, such as Anemia villosa, Baccharis platypoda and Vernonia decumbens.

Besides soil properties, a small difference in elevation can lead to significant changes in species composition and structure of highland communities in southeastern Brazil, with a marked decrease in the number of species with higher altitude (Neri et al., 2016; Campos et al., 2018). We hypothesized that altitude is an important environmental factor that accounts for the differences in highland vegetation. Thus, we suggest that both community structure and composition (i.e. high species turnover) may be related to altitude, as well as soil conditions, such as texture, higher nutrient contents and higher acidity levels.

Our analyses yielded novel ecological results on the relationship between soil, altitude and vegetation of plant communities that form vegetation islands over rocky outcrops in high altitude grasslands in Southeastern Brazil. A large degree of floristic (beta diversity) and structural differentiation over a short distance occurs with a high proportion of indicator species restricted to each peak. The structure and composition of plant communities of three adjacent peaks are related with 
soil and altitude. These environmental drivers were significantly related to both abundance and floristic composition allowing the identification of distinct groups of indicator species occurring in preferred habitats according to altitude and soil. Finally, we argue that indicator species analysis may be of great importance from the point of view of conservation (Ricotta, Carboni, \& Acosta, 2015; Campos et al., 2018), landscape mapping, design of natural reserves (De Cáceres et al., 2010), as well as in a monitoring program that aims to maintain or restore the ecological integrity of an ecosystem (Carignan \& Villard, 2002).

Ethical statement: authors declare that they all agree with this publication and made significant contributions; that there is no conflict of interest of any kind; and that we followed all pertinent ethical and legal procedures and requirements. All financial sources are fully and clearly stated in the acknowledgements section. A signed document has been filed in the journal archives.

\section{RESUMEN}

Diversidad beta, composición comunitaria y estructura de pastizales de tierras altas a lo largo de un gradiente altitudinal en el sureste de Brasil. Introducción: Los estudios sobre cómo el gradiente altitudinal determina la composición y estructura de la comunidad en los pastizales tropicales de gran altitud son limitados. Objetivo: Evaluar el patrón de composición de especies y estructura de comunidades vegetales y su relación con la altitud y las propiedades del suelo a lo largo de un gradiente altitudinal de tres afloramientos de roca granítica, en el Parque Estatal Serra do Brigadeiro, Minas Gerais, en el sureste de Brasil. Métodos: En cada sitio seleccionado, se establecieron 100 parcelas de $1 \times 1 \mathrm{~m}$, totalizando 300 parcelas en el área de estudio. Comparamos la composición florística, la cobertura relativa y la abundancia entre sitios. Se realizó un análisis de diversidad beta. También se realizaron un análisis de especies indicadoras y un análisis de correlación canónica para investigar las posibles relaciones entre variables abióticas (suelo y altitud) y bióticas (abundancias de especies indicadoras). Resultados: Muestreamos un total de 9276 individuos pertenecientes a 39 familias y 102 especies. Se observaron diferencias significativas entre los sitios con respecto a la composición, la abundancia y la cobertura. El análisis de especies indicadoras reveló que 57 especies (55.88 \%) eran indicadoras. La distribución de las abundancias de las especies indicadoras se correlacionó con variables ambientales. Conclusiones: Se pudo observar que la altitud y el suelo cumplen un papel importante en el control de la composición y la estructura de la comunidad, la diversidad beta y la distribución de especies en los pastizales de tierras altas estudiados.

Palabras clave: especies indicadoras; vegetación de montaña; afloramientos rocosos; cobertura vegetal; relación suelo-vegetación.

\section{REFERENCES}

Baselga, A. (2017). Partitioning abundance-based multiplesite dissimilarity into components: balanced variation in abundance and abundance gradients. Methods in Ecology and Evolution, 8, 799-808.

Benites, V.M., Schaefer, C.E.G.R., Simas, F.N.B., \& Santos, H.G. (2007). Soils associated with rock outcrops in the Brazilian mountain ranges Mantiqueira and Espinhaço. Revista Brasileira de Botânica, 30, 569-577.

Braun-Blanquet, J. (1979). Phytosociology. Basis for the study of plant communities. Madrid, España: $\mathrm{H}$. Blume Ediciones.

Campos, P.V., Villa, P.M., Nunes, J.A., Schaefer, C.E.G.R., Poremsbki, S., \& Neri, A.V. (2018). Plant diversity and community structure of Brazilian Páramos. Journal of Mountain Science, 15, 1186-1198.

Carignan, V., \& Villard, M.A. (2002). Selecting indicator species tomonitor ecological. Environmental Monitoringand Assessment, 78, 45-61.

Chao, A., Gotelli, N.J., Hsieh, T.C., Sander, E.L., Ma, K.H., Colwell, R.K., \& Ellison, A.M. (2014). Rarefaction and extrapolation with Hill numbers: A framework for sampling and estimation in species diversity studies. Ecological Monograph, 84, 45-67.

Crawley, M.J. (2013). The R Book ( $2^{\text {nd }}$ Ed.). London, United Kingdom: John Wiley \& Sons, Ltd.

Conceição, A.A., \& Pirani, J.R. (2007). Diversidade em quatro áreas de campos rupestres na Chapada Diamantina, Bahia, Brasil: espécies distintas, mas riquezas similares. Rodriguésia, 58, 193-206.

De Cáceres, M., \& Jansen, F. (2016). Relationship between Species and Groups of Sites. Package 'indicspecies'. Retrieved from: ftp://r-project.org/pub/R/web/packages/indicspecies/indicspecies.pdf

De Cáceres, M., Legendre, P., \& Moretti, M. (2010). Improving indicator species analysis by combining groups of sites. Oikos, 119, 1674-1684.

Dludlu, M.N., Chimphango, S.B.M., Stirton, C.H., \& Muasya, A.M. (2017). Distinct edaphic habitats are 
occupied by discrete legume assemblages with unique indicator species in the Cape Peninsula of South Africa. Journal of Plant Ecology, 11, 632-644.

Dufrêne, M., \& Legendre, P. (1997). Species assemblages and indicator species: the need for a flexible asymmetrical approach. Ecological Monographs, 67, 345-366.

Jacobi, C.M., \& do Carmo, F.F. (2011). Life-forms, pollination and seed dispersal syndromes in plant communities on ironstone outcrops, SE Brazil. Acta Botanica Brasilica, 25, 395-412.

Koleff, P., Gaston, K.J., \& Lennon, J.J. (2003). Measuring beta diversity for presence-absence data. Journal of Animal Ecology, 72, 367-382.

Körner, C. (2007). The use of 'altitude' in ecological research. Trends Ecology \& Evolution, 22, 569-574.

Legendre, P., \& Legendre, L. (2012). Numerical Ecology (3nd. Ed.). Amsterdam, Netherlands: Elsevier Science.

Le Stradic, S., Buisson, E., \& Fernandes, G.W. (2015). Vegetation composition and structure of some Neotropical mountain grasslands in Brazil. Journal of Mountain Science, 12, 864-877.

McCune, B., \& Mefford, M.J. (2011). PC-ORD: Multivariate Analysis of Ecological Data. Version 6.0. MjM Solfware Desing, Glaneden Beach, Oregon.

Messias, M.C.T.B., Leite, M.G.P., Meira-Neto, J.A.A., Kozovits, A.R, \& Tavares, R. (2013). Soil-vegetation relationship in quartzitic and ferruginous Brazilian rocky outcrops. Folia Geobotanica, 48, 509-521.

Neri, A.V., Borges, G.R.A., Meira-Neto, J.A.A., Magnago, L.F.S., Trotter, I.M., Schaefer, C.E.G.R., \& Porembski, S. (2016). Soil and altitude drives diversity and functioning of Brazilian Páramos (campo de altitude). Journal of Plant Ecology, 10, 731-743.

Porembski S. (2007). Tropical inselbergs: habitat types, adaptive strategies and diversity patterns. Revista Brasileira de Botânica, 30, 579-586.
R Core Team (2018). R:A Language and Environment for Statistical Computing. R Foundation for Statistical Computing, Vienna, Austria. Retrieved from: http// www.R-project.org

Ricotta, C., Carboni, M., \& Acosta, A.T.R. (2015). Let the concept of indicator species be functional! Journal of Vegetation Science, 26, 839-847.

Safford, H.D. (1999a). "Brazilian paramos I. An introduction to the physical environment and vegetation of the campos de altitude". Journal of Biogeography, 26, 693-712.

Safford, H.D. (1999b). "Brazilian Páramos II. Macro and mesoclimate of the campos de altitude and affinities with high mountain climates of the tropical Andes and Costa Rica". Journal of Biogeography, 26, 713-737.

Safford, H.D., \& Martinelli, G. (2000). Southeast Brazil. In S. Porembski \& W. Barthlott (Eds.), Inselbergs (pp. 339-389). Heidelberg, Germany: Springer-Verlag.

Safford, H.D. (2007). "Brazilian Páramos IV. Phytogeography of the campos de altitude". Journal of Biogeography, 34, 1701-1722.

Schaefer, C.E.G.R., Corrêa, G.R., Candido, H.G., Arruda, D.M., Nunes, J.A., Araujo, R.W., ... \& Neri, A.V. (2016). The Physical Environment of Rupestrian Grasslands (Campos Rupestres) in Brazil: Geological, Geomorphological and Pedological Characteristics, and Interplays. In G.W. Fernandes (Eds.), Ecology and Conservation of Mountaintop Grasslands in Brazil (pp. 15-53). Brazil: Springer International Publishing AG Switzerland.

Tinti, B.V., Schaefer, C.E.R.G., Nunes, J.A., Rodrigues, A.C., Fialho, I.F., \& Neri, A.V. (2015). Plant diversity on granite/gneiss rock outcrop at Pedra do Pato, Serra do Brigadeiro State Park, Brazil. Check List, 11,1780 . 